\title{
Quercetin, the active phenolic component in kiwifruit, prevents hydrogen peroxide-induced inhibition of gap-junction intercellular communication
}

\author{
Dong Eun Lee ${ }^{1,2}$, Bong Jik Shin ${ }^{1}$, Haeng Jeon Hur $^{1}$, Jong Hun Kim $^{2}$, Jiyoung Kim ${ }^{1,2}$, Nam Joo Kang ${ }^{1,2,3}$, \\ Dae Ok Kim ${ }^{4}$, Chang Yong Lee ${ }^{5}, \mathrm{Ki}$ Won Lee ${ }^{2 *}$ and Hyong Joo Lee $\mathrm{L}^{1 *}$ \\ ${ }^{1}$ Major in Biomodulation, WCU, Department of Agricultural Biotechnology, Research Institute for Agriculture and Life Sciences, \\ Seoul National University, Seoul 151-921, Republic of Korea \\ ${ }^{2}$ Department of Bioscience and Biotechnology, Bio/Molecular Informatics Center, Konkuk University, Seoul 143-701, Republic \\ of Korea \\ ${ }^{3}$ School of Applied Biosciences, Kyungpook National University, Daegu 702-701, Republic of Korea \\ ${ }^{4}$ Department of Food Science and Technology, Kyung Hee University, Yongin, Republic of Korea \\ ${ }^{5}$ Department of Food Science and Technology, Cornell University, Geneva, NY 14456, USA
}

(Received 10 August 2009 - Revised 11 December 2009 - Accepted 12 January 2010 - First published online 22 March 2010)

\begin{abstract}
We evaluated the effects of the two main kiwifruit cultivars (gold kiwifruit (GOK) and green kiwifruit (GRK)) and their active phenolic compound, quercetin, on $\mathrm{H}_{2} \mathrm{O}_{2}$-induced inhibition of gap-junction intercellular communication (GJIC) in WB-F344 rat liver epithelial cells. We found that both GOK and GRK protect WB-F344 cells from $\mathrm{H}_{2} \mathrm{O}_{2}$-induced inhibition of GJIC. The extracellular signal-regulated protein kinase 1/2 (ERK1/2) - connexin 43 (Cx43) signalling pathway is crucial for the regulation of GJIC, and both GOK and GRK blocked the $\mathrm{H}_{2} \mathrm{O}_{2}$-induced phosphorylation of $\mathrm{Cx} 43$ and ERK1/2 in WB-F344 cells. Quercetin alone attenuated the $\mathrm{H}_{2} \mathrm{O}_{2}$-mediated ERK1/2-Cx43 signalling pathway and consequently reversed $\mathrm{H}_{2} \mathrm{O}_{2}$-mediated inhibition of GJIC in WB-F344 cells. A free radical-scavenging assay using 1,1-diphenyl2-picrylhydrazyl showed that the scavenging activity of quercetin was higher than that of a synthetic antioxidant, butylated hydroxytoluene, per mol, suggesting that the chemopreventive effect of quercetin on $\mathrm{H}_{2} \mathrm{O}_{2}$-mediated inhibition of ERK1/2-Cx43 signalling and GJIC may be mediated through its free radical-scavenging activity. Since the carcinogenicity of reactive oxygen species such as $\mathrm{H}_{2} \mathrm{O}_{2}$ is attributable to the inhibition of GJIC, GOK, GRK and quercetin may have chemopreventive potential by preventing the inhibition of GJIC.
\end{abstract}

Connexin 43: Extracellular signal-regulated protein kinase 1/2: Gap-junction intercellular communication: Kiwifruit: Quercetin

Gap-junction intercellular communication (GJIC) is an important mode of cell-cell communication to help maintain homeostasis by facilitating direct exchanges of essential cellular metabolites and messengers less than 1-2 kDa including $\mathrm{Na}, \mathrm{K}, \mathrm{Ca}$, cyclic AMP and ATP in multicellular organisms $^{(1,2)}$. Multiple lines of evidence indicate that GJIC is dysregulated in most cancer cells and that its inhibition is strongly related to carcinogenesis ${ }^{(3,4)}$. Most tumour promoters, such as pesticides, peroxisome proliferators and dietary additives, are reported to inhibit GJIC; however, anti-tumour drugs can reverse GJIC disruption ${ }^{(5-7)}$. GJIC is regulated by gapjunction proteins connexins, and the closure of gap junctions is particularly mediated by phosphorylation-modulated conformational changes of connexin $43(\mathrm{Cx} 43)^{(8)}$.

Epidemiological studies indicate that a diet rich in antioxidant-containing fruits and vegetables can reduce the risk of cancer ${ }^{(9-11)}$. Specifically, kiwifruits have been used for the treatment of lung, liver and gastrointestinal (primarily stomach) cancers in traditional Chinese medicine, due to high levels of antioxidants ${ }^{(12-14)}$. Kiwifruit provides protection against oxidative DNA damage and enhances DNA repair, thereby protecting against mutagenic changes that can lead to transformation ${ }^{(15)}$. Kiwifruit inhibited sarcoma 180 growth in mice by $30-40 \%{ }^{(13)}$. Further, kiwifruit juice inhibited the growth of cancer cells in vitro ${ }^{(16,17)}$, and some kiwifruit extracts showed a high $95 \%$ inhibition of cancer growth by Ames' test ${ }^{(13)}$.

Expressed on a fresh-weight basis, kiwifruit possesses a total phenol content of $274 \mathrm{mg} / 100 \mathrm{~g}^{(18)}$. Although analyses of total phenolics in kiwifruit indicated the level of phenolic compounds to be low in comparison with other fruits ${ }^{(19)}$, a previous study showed that quercetin $\left(3,3^{\prime}, 4^{\prime}, 5,7\right.$-pentahydroxyflavone) is found in kiwifruit juice as the glycosides of quercetin ${ }^{(20)}$, and that quercetin is an important phenolic antioxidant in kiwifruit ${ }^{(21)}$. Depending on the methods of preparation, kiwi extract contains $0.63-1.06 \mathrm{mg}$ quercetin glycosides $/ 1^{(20)}$. Epidemiological studies have shown that quercetin consumption reduces the risk of developing cancer $^{(22)}$. Further, the chemopreventive activity of quercetin has been demonstrated in a variety of laboratory animal

Abbreviations: BHT, butylated hydroxytoluene; Cx43, connexin 43; DPPH, 1,1-diphenyl-2-picrylhydrazyl; ERK1/2, extracellular signal-regulated protein kinase 1/2; GJIC, gap-junction intercellular communication; GOK, gold kiwifruit; GRK, green kiwifruit.

* Corresponding authors: Dr Hyong Joo Lee, fax + 822873 5095, email leehyjo@snu.ac.kr; Dr Ki Won Lee, fax +82 234366178 , email kiwon@konkuk.ac.kr 
models, including azoxymethane-induced colonic tumorigenesis in mice ${ }^{(23)}$. Additionally, quercetin is reported to prevent the appearance of pre-neoplastic lesions in rat hepatocarcinogenesis ${ }^{(24)}$.

Although the potent chemopreventive activity of kiwifruit and quercetin has been demonstrated repeatedly, the molecular mechanisms underlying these effects are largely unknown. Recent reports suggest that the carcinogenicity of oxidative stress is attributable to the inhibition of $\mathrm{GJIC}^{(2)}$. Particularly, $\mathrm{H}_{2} \mathrm{O}_{2}$ is a well-known cancer promoter that disrupts GJIC ${ }^{(25-27)} \cdot \mathrm{H}_{2} \mathrm{O}_{2}$ inhibits GJIC in WB-F344 rat liver epithelial cells with a $50 \%$ inhibition $\left(\mathrm{I}_{50}\right)$ value of $200 \mu \mathrm{M}^{(27)}$. WB-F344 cells are stimulated directly by $\mathrm{H}_{2} \mathrm{O}_{2}$ and $\mathrm{H}_{2} \mathrm{O}_{2}$ promotes proliferation and transformation of WB-F344 cells ${ }^{(28)} \cdot \mathrm{H}_{2} \mathrm{O}_{2}$-mediated interference of GJIC has been reported to particularly correlate with the phosphorylation of $\mathrm{Cx}_{4} 43$ and extracellular signal-regulated protein kinase $(\mathrm{ERK})^{(27,29)}$. The present study was designed to investigate the effects of both the gold kiwifruit (GOK) and green kiwifruit (GRK) cultivars, and their active phenolic phytochemical quercetin, on the $\mathrm{H}_{2} \mathrm{O}_{2}$-mediated inhibition of GJIC.

\section{Materials and methods}

\section{Reagents}

1,1-Diphenyl-2-picrylhydrazyl (DPPH), lucifer yellow, SDS, acrylamide, $\mathrm{H}_{2} \mathrm{O}_{2}$, quercetin and butylated hydroxytoluene (BHT) were obtained from Sigma (St Louis, MO, USA). The antibodies against phosphorylated ERK1/2 (Tyr202/Tyr204) and total ERK1/2 were purchased from Cell Signaling Technology (Beverly, MA, USA). The antibody against Cx43 was purchased from Zymed (San Francisco, CA, USA). All other chemicals were obtained from Fisher (Springfield, NJ, USA).

\section{Preparation of kiwifruit extracts}

The two main kiwifruit cultivars, GOK, which has a yellow colour and non-astringent taste, and GRK, which has a green colour and astringent taste, were supplied by the New Zealand Kiwifruit Marketing Board (ZESPRI). These kiwifruits were carefully pared, frozen and dried. The freezedried kiwifruits were ground to powder and stored at $-20^{\circ} \mathrm{C}$ until used. Kiwifruit extracts were generated by mixing $10 \mathrm{~g}$ lyophilised kiwifruit with $100 \mathrm{ml}$ of $80 \%$ aqueous methanol. The kiwifruit-methanol mixture was sonicated for $20 \mathrm{~min}$ with continuous $\mathrm{N}_{2}$ gas purging. The mixture was filtered through Whatman no. 2 filter paper (Whatman International Ltd, Maidstone, Kent, UK) using a chilled Buchner funnel and then rinsed with $50 \mathrm{ml}$ methanol. The solid filter cake was then re-extracted by repeating the above steps under the same conditions. The two filtrates were combined, and an additional $50 \mathrm{ml}$ of $80 \%$ aqueous methanol was added. The solvent was evaporated using a rotary evaporator under reduced pressure at $40^{\circ} \mathrm{C}$. The extract was dissolved in $50 \mathrm{ml}$ of $100 \%$ methanol and made up to the final volume of $100 \mathrm{ml}$ with distilled deionised water. The solution was then centrifuged in a Sorvall ${ }^{\circledR}$ RC-5B Refrigerated Superspeed Centrifuge (Du Pont, Wilmington, DE, USA) at $12000 \mathrm{~g}$ for $20 \mathrm{~min}$. The final extracted product was stored at $-4^{\circ} \mathrm{C}$ until used.

\section{Cell culture}

WB-F344 rat liver epithelial cells (WB-F344 cells) were kindly provided by Dr J. E. Trosko (Michigan State University, MI, USA). WB-F344 cells were cultured in Dulbecco's modified Eagle's medium (GIBCO, Gaithersburg, MD, USA), supplemented with $10 \%$ fetal bovine serum (GIBCO) and penicillin-streptomycin (GIBCO) at $37^{\circ} \mathrm{C}$ in a $5 \% \mathrm{CO}_{2}$ humidified incubator (Forma Scientific, Marietta, OH, USA).

\section{Bioassay of gap-junction intercellular communication}

GJIC was measured by the scrape-loading-dye-transfer technique as described previously ${ }^{(26)}$. Briefly, WB-F344 cells were pre-incubated with kiwifruit extract or quercetin for $30 \mathrm{~min}$ and then stimulated with $100 \mu \mathrm{M}-\mathrm{H}_{2} \mathrm{O}_{2}$ for $1 \mathrm{~h}$. After $\mathrm{H}_{2} \mathrm{O}_{2}$ treatment, cells were washed twice with PBS. Next, lucifer yellow was added to the washed cells, and three scrapes were made using a scalpel with a surgical-steel blade under low light intensity. Each scrape traversed a large group of confluent cells. After $3 \mathrm{~min}$ of incubation, the cells were washed four times with PBS and then fixed with a $4 \%$ formalin solution. Communicating cells showing green fluorescence were distinguishable from cells that are not communicating under an inverted fluorescence microscope $(\mathrm{I} \times 70$; Olympus, Okaya, Japan). The number of communicating cells was counted.

\section{Western blot analysis}

Western blot analysis was performed to measure the protein level of Cx43, ERK1/2 and phosphorylated ERK1/2. Briefly, total cell lysates were suspended in $4 \times$ sample buffer (8\% SDS, $20 \%$ glycerin, $250 \mathrm{~mm}$-2-amino-2-(hydroxymethyl) propane-1,3-diol (Tris)- $\mathrm{HCl}(\mathrm{pH} 7 \cdot 5), 0.2 \%$ bromophenol blue and $40 \mathrm{mM}$-dithiothreitol), heated at $95^{\circ} \mathrm{C}$ for $5 \mathrm{~min}$ and separated by SDS-PAGE on a $12.5 \%$ polyacrylamide gel. The proteins were then transferred to a $0.45 \mu \mathrm{m}$ polyvinylidene fluoride transfer membrane (Gelman Laboratories, Ann Arbor, MI, USA) and incubated in a blocking buffer (25 mM-Tris- $\mathrm{HCl}(\mathrm{pH} \mathrm{7.5)}, 150 \mathrm{~mm}-\mathrm{NaCl}, 0.05 \%$ Tween-20 and $5 \%$ skimmed milk). Blots were probed with primary antibodies and then horseradish peroxidase-conjugated goat anti-mouse IgG secondary antibodies (Zymed Laboratories), according to the manufacturer's instructions. For visual detection, blots were developed using an enhanced chemiluminescence system (Amersham Biosciences, Little Chalfont, Bucks, UK).

\section{1,1-Diphenyl-2-picrylhydrazyl radical-scavenging activity assay}

The DPPH radical-scavenging activities of resveratrol and BHT were measured using the method described by Brand-Williams et al. with minor modifications ${ }^{(30,31)}$. DPPH was dissolved in $80 \%$ aqueous methanol. A $0.1 \mathrm{ml}$ volume of quercetin or BHT at various concentrations was added to $2.9 \mathrm{ml}$ of the DPPH radical solution. The mixture was then shaken vigorously and incubated in the dark at $23^{\circ} \mathrm{C}$ for $30 \mathrm{~min}$. Absorbance at $517 \mathrm{~nm}$ was measured using a spectrophotometer (Hitachi, Tokyo, Japan). 


\section{Statistical analysis}

All experiments were repeated at least three times unless otherwise stated. Results are presented as mean values and standard deviations of triplicates. Comparisons between two groups were analysed using Student's $t$ test. Probability values of $P<0.05$ were considered statistically significant.

\section{Results}

\section{Kiwifruit extracts prevented hydrogen peroxide-induced} inhibition of gap-junction intercellular communication

The effects of two kiwifruit extracts on the $\mathrm{H}_{2} \mathrm{O}_{2}$-mediated inhibition of GJIC in WB-F344 cells were assessed using the scrape-loading-dye-transfer technique. The distance that the dye travelled perpendicular to the scrape was observed under an inverted fluorescence microscope as shown in Fig. 1(a). Untreated WB-F344 cells exhibited active GJIC (Fig. 1(a-i)). Treatment of cells with $100 \mu \mathrm{M}-\mathrm{H}_{2} \mathrm{O}_{2}$ for $1 \mathrm{~h}$ resulted in the dye travelling a shorter distance from the scrape, indicating an inhibition of GJIC (Fig. 1(a-ii)). WBF344 cells pre-treated with 10 and $20 \mathrm{mg} / \mathrm{ml}$ GOK and GRK extracts for $30 \mathrm{~min}$ showed a reduction in the $\mathrm{H}_{2} \mathrm{O}_{2}$-induced inhibition of GJIC.

The data were quantified by normalising the number of communicating WB-F344 cells in the untreated control to $100 \%$ (Fig. 1(b-i)). Treatment of cells with $100 \mu \mathrm{M}-\mathrm{H}_{2} \mathrm{O}_{2}$ for $1 \mathrm{~h}$ reduced GJIC to about $35 \%$ (Fig. 1(b-ii)). However, pre-treatment of cells with $20 \mathrm{mg} / \mathrm{ml}$ of either GOK or GRK extracts completely prevented the $\mathrm{H}_{2} \mathrm{O}_{2}$-induced inhibition of GJIC (Fig. 1(b-iv and vi)).

\section{Kiwifruit extracts blocked hydrogen peroxide-induced phosphorylation of connexin 43 and extracellular signal-regulated protein kinase $1 / 2$}

$\mathrm{H}_{2} \mathrm{O}_{2}$-mediated inhibition of $\mathrm{GJIC}$ has been reported to correlate with the phosphorylation of $\mathrm{Cx} 43$ and $\mathrm{ERK}^{(27,29)}$. To determine if kiwifruit extracts function by blocking the phosphorylation of these proteins, Western blot analysis with antibodies specific to $\mathrm{Cx} 43$, phosphorylated ERK1/2 and total ERK1/2 was performed (Fig. 2). Four bands corresponding to $\mathrm{Cx} 43$ ( $\mathrm{P} 0, \mathrm{P} 1, \mathrm{P} 2$ and $\mathrm{P} 3$ ) were detected in the untreated control WB-F344 cells (Fig. 2(a)). The electrophoretic mobility of $\mathrm{Cx} 43$ is slower (upward shifted) according to the degree of phosphorylation. The P0 band represents non-phosphorylated $\mathrm{Cx} 43, \mathrm{P} 1$ is mono-phosphorylated, and the P2 and P3 bands represent hyper-phosphorylated Cx43. The ratios of phosphorylated $\mathrm{Cx} 43$ were demonstrated in densitometry scans for the quantitative analysis. The horizontal lines represent the position of each phosphorylated $\mathrm{Cx} 43$. In a vertical lane, the more a band is intensive, the more the graph moves from left to right. In the present study, data are representative of three independent experiments. Treatment of WB-F344 cells with $20 \mathrm{mg} / \mathrm{ml}$ of either GOK or GRK for $30 \mathrm{~min}$ had no effect on the phosphorylation status of Cx43. Treatment of WB-F344 cells with $\mathrm{H}_{2} \mathrm{O}_{2}$ at $100 \mu \mathrm{M}$ for $1 \mathrm{~h}$ caused a decrease in the $\mathrm{P} 0$ and $\mathrm{P} 1$ bands and a concomitant increase in the $\mathrm{P} 2$ and $\mathrm{P} 3$ bands, indicating that $\mathrm{H}_{2} \mathrm{O}_{2}$ activated the hyper-phosphorylation of $\mathrm{Cx} 43$ (Fig. 2(a)). Pre-treatment with $20 \mathrm{mg} / \mathrm{ml}$ of GOK or GRK (a)
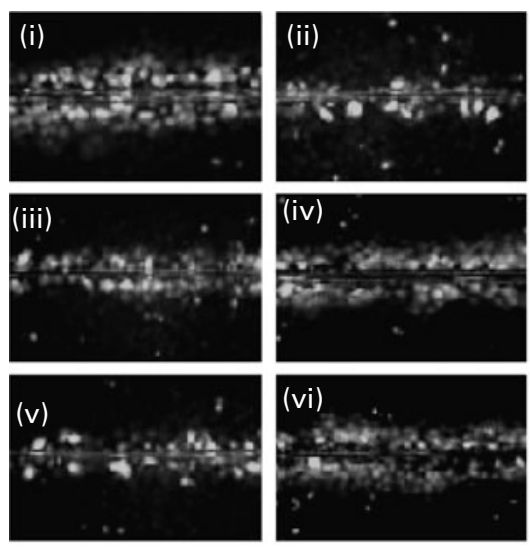

(b)

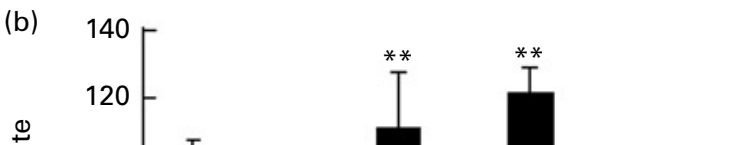

Fig. 1. Effects of gold kiwifruit (GOK) and green kiwifruit (GRK) extracts on the $\mathrm{H}_{2} \mathrm{O}_{2}$-induced inhibition of gap-junction intercellular communication (GJIC) in WB-F344 cells. GJIC was assessed using the scrape-loadingdye-transfer method under an inverted fluorescence microscope $(100 \times)$. (a) Representative photographs of the following treatments: (i) untreated control (distilled deionised water $\left(\mathrm{ddH}_{2} \mathrm{O}\right.$ ) as vehicle) for $30 \mathrm{~min}$; (ii) $\mathrm{H}_{2} \mathrm{O}_{2}$ $(100 \mu \mathrm{M})$ for $1 \mathrm{~h}$; (iii) GOK extract $(10 \mathrm{mg} / \mathrm{ml})$ for $30 \mathrm{~min}$ and then $\mathrm{H}_{2} \mathrm{O}_{2}$ $(100 \mu \mathrm{M})$ for $1 \mathrm{~h}$; (iv) GOK extract $(20 \mathrm{mg} / \mathrm{ml})$ for $30 \mathrm{~min}$ and then $\mathrm{H}_{2} \mathrm{O}_{2}(100 \mu \mathrm{M})$ for $1 \mathrm{~h}$; (v) GRK extract $(10 \mathrm{mg} / \mathrm{ml})$ for $30 \mathrm{~min}$ and then $\mathrm{H}_{2} \mathrm{O}_{2}(100 \mu \mathrm{m})$ for $1 \mathrm{~h}$; (vi) GRK extract $(20 \mathrm{mg} / \mathrm{ml})$ for 30 min and then $\mathrm{H}_{2} \mathrm{O}_{2}$ $(100 \mu \mathrm{M})$ for $1 \mathrm{~h}$. (b) The number of communicating cells was counted, and the number of communicating cells in the untreated control was normalised to $100 \%$. The relative rate of GJIC for each of the treatment conditions was calculated as the percentage of the untreated control. Values are means ( $n$ 3), with standard deviations represented by vertical bars. ${ }^{* \star}$ The mean number of communicating cells was significantly higher than that in the $\mathrm{H}_{2} \mathrm{O}_{2}$-only treatment $(P<0.01)$.

extracts for $30 \mathrm{~min}$ blocked the $\mathrm{H}_{2} \mathrm{O}_{2}$-mediated hyperphosphorylation of $\mathrm{Cx} 43$, measured as a decrease in the $(\mathrm{P} 2+\mathrm{P} 3):(\mathrm{P} 0+\mathrm{P} 1)$ ratio.

To identify the molecular mechanism by which kiwifruit extracts prevent $\mathrm{H}_{2} \mathrm{O}_{2}$-mediated inhibition of GJIC, we examined the phosphorylation status of ERK1/2 (Fig. 2(b)). Treatment of WB-F344 cells with $20 \mathrm{mg} / \mathrm{ml}$ of either GOK or GRK for $30 \mathrm{~min}$ had no effect on the phosphorylation of ERK1/2. In contrast, treatment with $100 \mu \mathrm{M}-\mathrm{H}_{2} \mathrm{O}_{2}$ for $1 \mathrm{~h}$ induced ERK1/2 phosphorylation. However, pre-treatment of WB-F344 cells with $20 \mathrm{mg} / \mathrm{ml}$ of GOK and GRK for $30 \mathrm{~min}$ blocked $\mathrm{H}_{2} \mathrm{O}_{2}$-induced phosphorylation of ERK1/2. 
(a)

$\begin{array}{rrrrrrr}\mathrm{H}_{2} \mathrm{O}_{2}(100 \mu \mathrm{M}) & - & + & - & - & + & + \\ \text { GOK extract }(20 \mathrm{mg} / \mathrm{ml}) & - & - & + & - & + & - \\ \text { GRK extract }(20 \mathrm{mg} / \mathrm{ml}) & - & - & - & + & - & +\end{array}$
Cx43

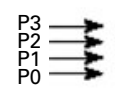

$\mathrm{Cx} 43$

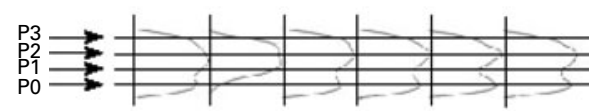

(b)

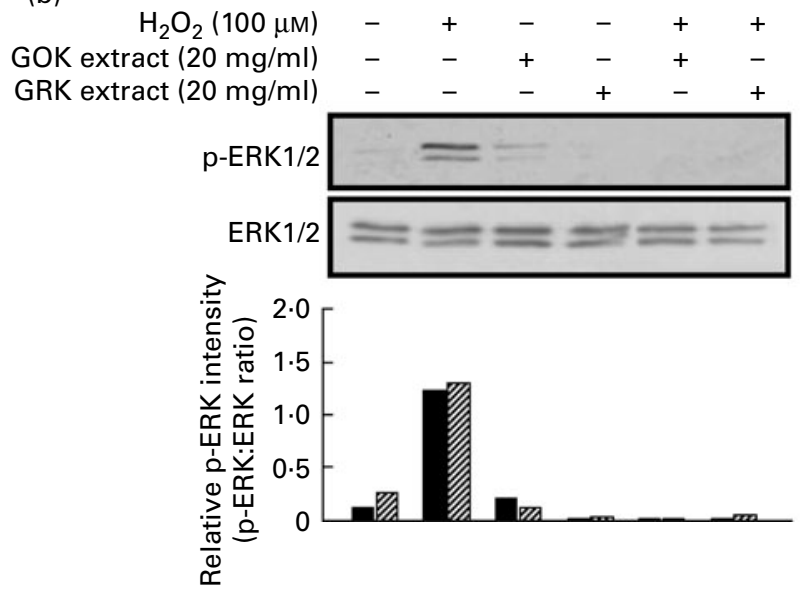

Fig. 2. Effects of gold kiwifruit (GOK) and green kiwifruit (GRK) extracts on the $\mathrm{H}_{2} \mathrm{O}_{2}$-induced phosphorylation of connexin $43(\mathrm{Cx} 43)$ and extracellular signal-regulated protein kinase $1 / 2$ (ERK1/2) in WB-F344 cells: lane 1, untreated control (distilled deionised water $\left(\mathrm{dd}_{2} \mathrm{O}\right)$ as vehicle for $1 \mathrm{~h}$ ); lane 2, $\mathrm{H}_{2} \mathrm{O}_{2}(100 \mu \mathrm{M})$ for $1 \mathrm{~h}$; lane 3 , GOK extract $(20 \mathrm{mg} / \mathrm{ml})$ for $30 \mathrm{~min}$; lane 4 , GRK extract $(20 \mathrm{mg} / \mathrm{ml})$ for $30 \mathrm{~min}$; lane 5 , GOK extract $(20 \mathrm{mg} / \mathrm{ml})$ for $30 \mathrm{~min}$ and then $\mathrm{H}_{2} \mathrm{O}_{2}(100 \mu \mathrm{M})$ for $1 \mathrm{~h}$; lane 6 , GRK extract $(20 \mathrm{mg} / \mathrm{ml})$ for $30 \mathrm{~min}$ and then $\mathrm{H}_{2} \mathrm{O}_{2}(100 \mu \mathrm{M})$ for $1 \mathrm{~h}$. (a) The phosphorylation status of $\mathrm{C} \times 43$ was analysed by Western blot analysis as described in the Materials and methods. The diagram shows the intensity of each $\mathrm{Cx} 43$ band. (b) The levels of phosphorylated ERK1/2 (p-ERK1/2) and total ERK1/2 were analysed by Western blot analysis as described in the Materials and methods. The bar graphs (bottom) show the p-ERK:ERK ratio, which was determined

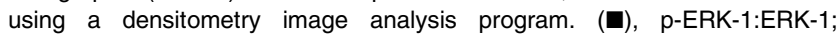
(造), p-ERK-2:ERK-2.

Quercetin prevented hydrogen peroxide-induced inhibition of gap-junction intercellular communication

Previous studies have shown that quercetin and quercetin glycosides are the active phenolic compounds found in kiwifruit ${ }^{(20)}$. Since kiwifruit extracts protected against $\mathrm{H}_{2} \mathrm{O}_{2}$ induced inhibition of GJIC, we next sought to determine if purified quercetin prevented $\mathrm{H}_{2} \mathrm{O}_{2}$-mediated inhibition of GJIC in WB-344 cells. Untreated WB-F344 cells had active GJIC (Fig. 3(a-i)); however, treatment with $100 \mu \mathrm{M}-\mathrm{H}_{2} \mathrm{O}_{2}$ for $1 \mathrm{~h}$ resulted in a clear inhibition of GJIC (Fig. 3(a-ii)). In contrast, pre-treatment of WB-F344 cells with 25 or $100 \mu \mathrm{M}$-quercetin for $30 \mathrm{~min}$ before $\mathrm{H}_{2} \mathrm{O}_{2}$ exposure reduced the extent of $\mathrm{H}_{2} \mathrm{O}_{2}$-mediated inhibition of GJIC. As above, the data were quantified by normalising the number of communicating WB-F344 cells in the untreated control to $100 \%$ (Fig. 3(b-i)). Treatment of WB-F344 cells with $100 \mu \mathrm{M}-\mathrm{H}_{2} \mathrm{O}_{2}$ for $1 \mathrm{~h}$ decreased the GJIC by about $50 \%$ (Fig. 3(b-ii)). Pre-treatment with 25 or $100 \mu \mathrm{M}$-quercetin completely blocked the $\mathrm{H}_{2} \mathrm{O}_{2}$-induced inhibition of GJIC (Fig. 3(b-iii and iv)).
Quercetin blocked hydrogen peroxide-induced phosphorylation of connexin 43 and extracellular signal-regulated protein kinase $1 / 2$

We next sought to determine if quercetin was the component of kiwifruit extracts responsible for blocking the $\mathrm{H}_{2} \mathrm{O}_{2}$ induced phosphorylation of $\mathrm{Cx} 43$ and ERK1/2 and thereby preventing the inhibition of GJIC. As shown above, treatment of WB-F344 cells with $100 \mu \mathrm{M}-\mathrm{H}_{2} \mathrm{O}_{2}$ for $1 \mathrm{~h}$ induced the hyper-phosphorylation of $\mathrm{Cx} 43$ (Fig. 4(a)) and phosphorylation of ERK1/2 (Fig. 4(b)). Pre-treatment of WB-F334 cells with 25 or $100 \mu \mathrm{M}$-quercetin for $30 \mathrm{~min}$ decreased the ratio of hyper-phosphorylated to non- or mono-phosphorylated Cx43 ((P2 + P3): $(\mathrm{P} 0+\mathrm{P} 1))$ induced by $\mathrm{H}_{2} \mathrm{O}_{2}$ treatment (Fig. 4(a)). Further, quercetin pre-treatment also blocked the $\mathrm{H}_{2} \mathrm{O}_{2}$-induced phosphorylation of ERK1/2 (Fig. 4(b)).

(a)
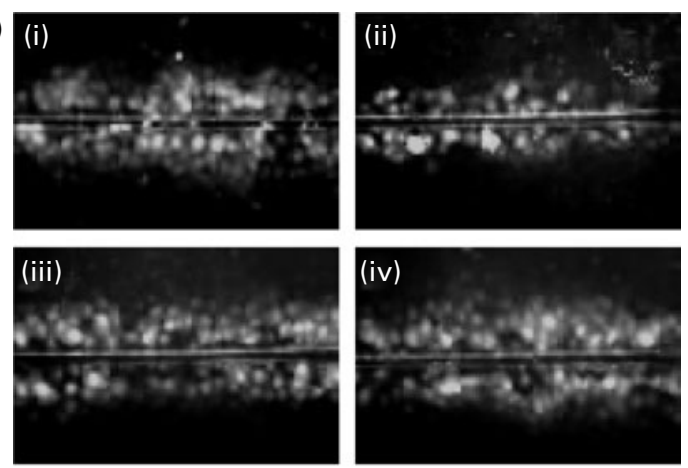

(b)

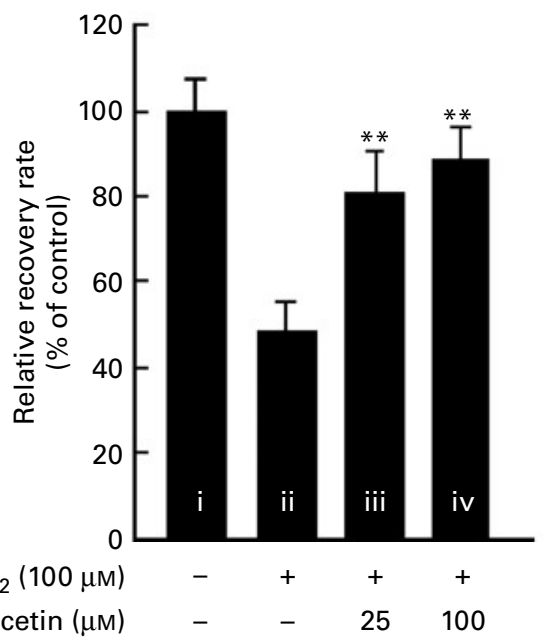

Fig. 3. Effects of quercetin on the $\mathrm{H}_{2} \mathrm{O}_{2}$-induced inhibition of gap-junction intercellular communication (GJIC) in WB-F344 cells. (a) GJIC was assessed using the scrape loading-dye transfer method under an inverted fluorescence microscope $(100 \times)$. Representative photographs of each treatment: (i) Untreated control (distilled deionised water $\left(\mathrm{ddH}_{2} \mathrm{O}\right)$ as vehicle for $1 \mathrm{~h}$ ); (ii) $\mathrm{H}_{2} \mathrm{O}_{2}(100 \mu \mathrm{M})$ for $1 \mathrm{~h}$; (iii) quercetin $(25 \mu \mathrm{M})$ for $30 \mathrm{~min}$ and then $\mathrm{H}_{2} \mathrm{O}_{2}(100 \mu \mathrm{M})$ for $1 \mathrm{~h}$; (iv) quercetin $(100 \mu \mathrm{M})$ for $30 \mathrm{~min}$ and then $\mathrm{H}_{2} \mathrm{O}_{2}$ $(100 \mu \mathrm{M})$ for $1 \mathrm{~h}$. (b) The number of communicating cells was counted and the number of communicating cells in the untreated control was normalised to $100 \%$. The relative rate of GJIC for each of the treatment conditions was calculated as the percentage of the untreated control. Values are means ( $n$ 3), with standard deviations represented by vertical bars. ${ }^{* *}$ The mean number of communicating cells was significantly higher than that in the $\mathrm{H}_{2} \mathrm{O}_{2}$-only treatment $(P<0.01)$. 
(a)

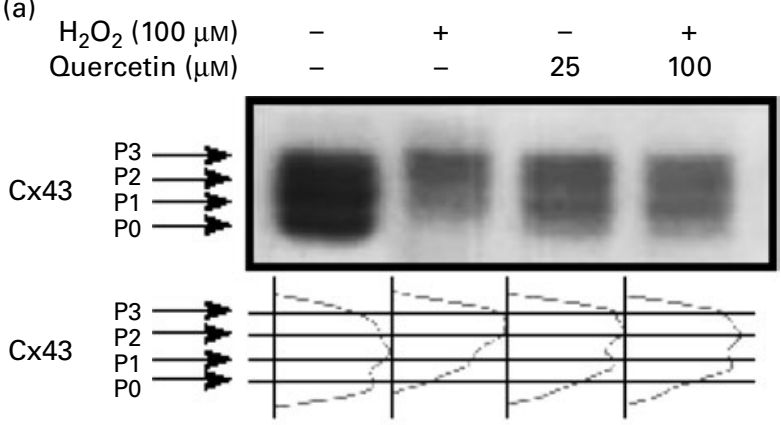

(b)
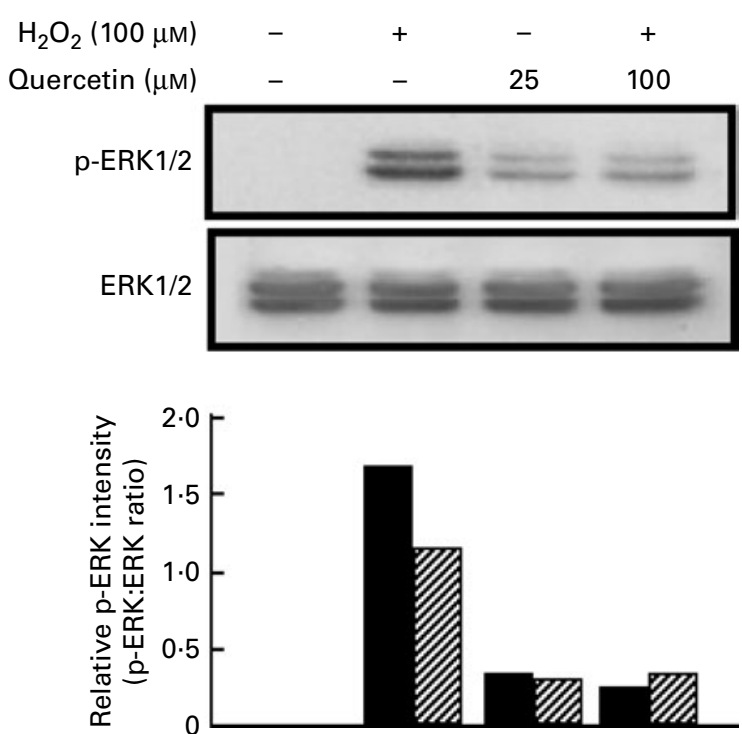

Fig. 4. Effects of quercetin on the $\mathrm{H}_{2} \mathrm{O}_{2}$-induced phosphorylation of connexin $43(\mathrm{C} \times 43)$ and extracellular signal-regulated protein kinase 1/2 (ERK1/2) in WB-F344 cells: lane 1, untreated control (distilled deionised water $\left(\mathrm{ddH}_{2} \mathrm{O}\right)$ as vehicle for $1 \mathrm{~h}$ ); lane $2, \mathrm{H}_{2} \mathrm{O}_{2}(100 \mu \mathrm{M})$ for $1 \mathrm{~h}$; lane 3 , quercetin $(25 \mu \mathrm{M})$ for $30 \mathrm{~min}$ and then $\mathrm{H}_{2} \mathrm{O}_{2}(100 \mu \mathrm{M})$ for $1 \mathrm{~h}$; lane 4, quercetin $(100 \mu \mathrm{M})$ for $30 \mathrm{~min}$ and then $\mathrm{H}_{2} \mathrm{O}_{2}(100 \mu \mathrm{M})$ for $1 \mathrm{~h}$. (a) The phosphorylation status of Cx43 was analysed by Western blot analysis as described in the Materials and methods. The diagram shows the intensity of each $\mathrm{C} x 43$ band. (b) The levels of phosphorylated ERK1/2 (p-ERK1/2) and total ERK1/2 were analysed by Western blot analysis as described in the Materials and methods. The bar graphs (bottom) show the p-ERK:ERK ratio, which was determined

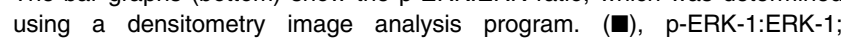
(级), p-ERK-2:ERK-2.

\section{Free radical-scavenging activity of quercetin}

We measured the free radical-scavenging activity of quercetin and compared its activity with BHT, a synthetic phenolic antioxidant used in foods. The amount of free radicals produced by DPPH alone was normalised to $100 \%$, and increasing amounts of BHT or quercetin were added to assess their activities (Fig. 5). Both BHT and quercetin exhibited dosedependent free radical-scavenging activity. Importantly, 50 or $100 \mu \mathrm{M}$-quercetin efficiently scavenged the free radicals produced by DPPH and had superior scavenging activity to that of BHT. As shown above, pre-treatment of cells with these concentrations of quercetin suppressed the phosphorylation of $\mathrm{Cx} 43$ and ERK1/2, thereby preventing the inhibition of GJIC and suggesting a possible link between the free radical-scavenging activity and protection of GJIC.

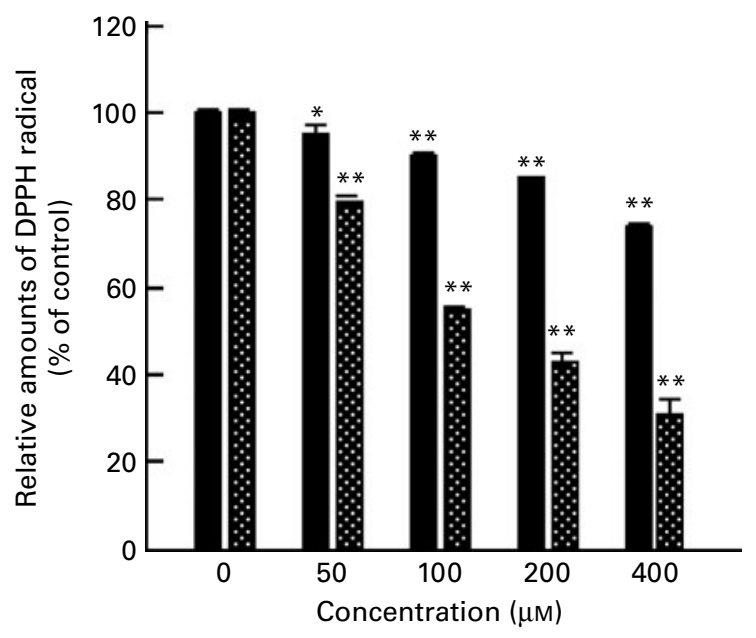

Fig. 5. Free radical-scavenging activity of butylated hydroxytoluene (BHT; $\mathbf{\square})$ and quercetin ( $\mathrm{s})$. The relative amount of free radicals generated by 1,1-diphenyl-2-picrylhydrazyl (DPPH) was determined as described in the Materials and methods. The amount of free radicals generated by DPPH was set at $100 \%$ and the relative amount of each free radical after treatment with $\mathrm{BHT}$ and quercetin was evaluated. Values are means ( $n 3)$, with standard deviations represented by vertical bars. Mean value was significantly lower than than of the untreated control: ${ }^{\star} P<0.05,{ }^{* \star} P<0.01$.

\section{Discussion}

In the present report, we used a cell culture-based model system to evaluate the ability of kiwifruit extracts or purified quercetin, the active phenolic compound found in kiwifruit, to prevent $\mathrm{H}_{2} \mathrm{O}_{2}$-induced inhibition of GJIC. WB-F344 cells that were pre-treated with an extract from either the GOK or GRK cultivar maintained normal GJIC after challenge with $100 \mu \mathrm{M}-\mathrm{H}_{2} \mathrm{O}_{2}$ (Fig. 1). Further, GOK- or GRK-treated cells had a reduced level of $\mathrm{Cx} 43$ and ERK1/2 phosphorylation upon $\mathrm{H}_{2} \mathrm{O}_{2}$ treatment, and phosphorylation of these proteins is known to be associated with impaired GJIC. The protective effects of the kiwifruit extracts were mimicked by the treatment of cells with quercetin alone, indicating that quercetin is the active component of the kiwifruit extracts. Quercetin also had substantial free radical-scavenging activity, which was significantly greater than the synthetic phenolic antioxidant BHT. Together, these data suggest that the protective effects of quercetin on GJIC may be mediated by its antioxidant properties.

Many population-based studies highlight the association between diets rich in the macronutrients and micronutrients found in fruits and vegetables with a reduced risk of developing cancer ${ }^{(32)}$. Kiwifruits have been shown to have cancerpreventative activities in several cancer models ${ }^{(13,15-17)}$; however, the active compounds in kiwifruits that exert these anti-tumour activities have not been clearly identified. Recently, attention has been focused on phytochemicals, which are non-nutritive components of plant-based diets that possess cancer-preventive properties ${ }^{(32)}$. These phytochemicals act to prevent cancer by blocking the initiation or reversing the promotion of carcinogenesis ${ }^{(32)}$. Quercetin is an antioxidant found in substantial quantities in kiwifruits ${ }^{(20,21)}$, suggesting that quercetin may be the primary phytochemical in kiwifruits that is responsible for the cancer-preventative properties. 
Multiple lines of evidence indicated that the inhibition of GJIC is a carcinogenic and tumour-promoting process ${ }^{(3,4)}$. Most normal cells exhibit functional GJIC, but most cancer cells exhibit impaired $\mathrm{GJIC}^{(3,4)}$. Natural chemopreventive compounds, such as germanium dioxide ${ }^{(5)}$, honeybee propolis $^{(33)}$, green tea and components of Korean ginseng ${ }^{(7,29)}$ have been shown to prevent or abolish inhibition of GJIC. Here we found that kiwifruit extracts from both GOK and GRK, as well as quercetin, blocked $\mathrm{H}_{2} \mathrm{O}_{2}$-induced inhibition of GJIC, suggesting that the chemopreventive activity of kiwifruits and quercetin may be mediated by preventing the inhibition of GJIC from oxidative stress-mediated injury.

The mechanism by which oxidative stress inhibits GJIC involves conformational changes in gap junctions due to the phosphorylation of $\mathrm{Cx} 43$, a major component of gap-junction channels ${ }^{(5,33,34)}$. Inhibition of GJIC also involves the activation of mitogen-activated protein kinases (MAPK) ${ }^{(26)}$. In particular, phosphorylation of ERK was reported to play a key role in the inhibition of GJIC in vitro ${ }^{(35,36)}$. Pharmacological inhibitor of MAPK kinase 1/2 (MEK1/2, an ERK upstream kinase) recovered $\mathrm{H}_{2} \mathrm{O}_{2}$-induced inhibition of GJIC up to $100 \%$; however, an inhibitor of p38 MAPK showed only partial protection ${ }^{(37)}$. A pharmacological inhibitor of c-Jun N-terminal kinases (JNK) did not show any protection (data not shown). Previous studies demonstrated that phosphorylation of $\mathrm{Cx} 43$ and ERK1/2 are important events controlling $\mathrm{H}_{2} \mathrm{O}_{2}$-induced inhibition of GJIC in WB-F344 cells $^{(25,26)}$. We observed that kiwifruit extracts from both GOK and GRK, and quercetin alone, blocked $\mathrm{H}_{2} \mathrm{O}_{2}$-induced phosphorylation of ERK $1 / 2$ and $\mathrm{Cx} 43$, thereby protecting GJIC in WB-F344 cells. These data suggest that quercetin mediates its effects by preventing oxidative stress-mediated activation of the ERK1/2-Cx43 signalling pathway.

Using an automated oxygen radical absorbance capacity assay, kiwifruit was shown to have greater antioxidant activity than grapefruit, apple or pear in vitro ${ }^{(38)}$. Increased antioxidant activity was also found in the plasma of human subjects fed kiwifruit juice, demonstrating the bioavailability of kiwifruit antioxidants in $\operatorname{man}^{(39)}$. The antioxidant activity of kiwifruit might play a role in the suppression of $\mathrm{H}_{2} \mathrm{O}_{2}$-induced phosphorylation of ERK $1 / 2$ and $\mathrm{Cx} 43$. This is supported by the superior free radical-scavenging activity of quercetin over BHT (Fig. 5). Together, these data suggest that the antioxidant properties of quercetin may be responsible for the suppression of $\mathrm{H}_{2} \mathrm{O}_{2}$-induced phosphorylation of ERK1/2 and $\mathrm{Cx} 43$ and prevention of GJIC inhibition.

In summary, kiwifruit extracts and quercetin alone prevented $\mathrm{H}_{2} \mathrm{O}_{2}$-induced inhibition of GJIC by blocking the oxidative stress-induced activation of the ERK1/2 and Cx43 signalling pathway. The present results suggest that the consumption of kiwifruit or adding quercetin as a dietary supplement might be an effective means to lowering the risk of developing cancer.

\section{Acknowledgements}

The present study was supported by research grants from Zespri, BioGreen21 Programme (nos. 20070301-034-042 and 2007 0301-034-027), the Rural Development Administration, Republic of Korea, and WCU programme (R31-2008-00-10056-0) and Priority Research Centers Programme (2009-0093824) through the Korea Science and Engineering Foundation funded by the Ministry of Education, Science and Technology.

All authors have contributed to the conception and design of the experiment, and acquisition of the data and their subsequent analysis and interpretation. Similarly, all authors have been involved in the critical revision of the paper and have approved the final version of the paper.

There are no conflicts of interest to declare by any of the authors.

\section{References}

1. Kumar MN \& Gilula NB (1996) The gap junction communication channel. Cell 84, 381-388.

2. King TJ \& Bertram JS (2005) Connexins as targets for cancer chemoprevention and chemotherapy. Biochim Biophys Acta 1719, $146-160$.

3. Trosko JE (1987) Mechanisms of tumor promotion: possible role of inhibited intercellular communication. Eur J Cancer Clin Oncol 23, 599-601.

4. Trosko JE \& Ruch RJ (1998) Cell-cell communication in carcinogenesis. Front Biosci 3, d208-d236.

5. Kang KS, Yun JW, Yoon B, et al. (2001) Preventive effect of germanium dioxide on the inhibition of gap junctional intercellular communication by TPA. Cancer Lett 166, 147-153.

6. Sai K, Kang KS, Hirose A, et al. (2001) Inhibition of apoptosis by pentachlorophenol in v-myc-transfected rat liver epithelial cells: relation to down-regulation of gap junctional intercellular communication. Cancer Lett 173, 163-174.

7. Kang KS, Lee YS, Kim HS, et al. (2002) DI-(2-ethylhexyl) phthalate-induced cell proliferation is involved in the inhibition of gap junctional intercellular communication and blockage of apoptosis in mouse Sertoli cells. J Toxicol Environ Health A 65, 447-459.

8. Solan JL \& Lampe PD (2009) Connexin 43 phosphorylation: structural changes and biological effects. Biochem J 419, $261-272$.

9. Birt DF, Hendrich S \& Wang W (2001) Dietary agents in cancer prevention: flavonoids and isoflavonoids. Pharmacol Ther 90, $157-177$.

10. Surh YJ (2002) Anti-tumor promoting potential of selected spice ingredients with antioxidative and anti-inflammatory activities: a short review. Food Chem Toxicol 40, 1091-1097.

11. Lee KW, Lee HJ, Surh YJ, et al. (2003) Vitamin C and cancer chemoprevention: reappraisal. Am J Clin Nutr 78, 1074-1078.

12. Collins BH, Horska A, Hotten PM, et al. (2001) Kiwifruit protects against oxidative DNA damage in human cells and in vitro. Nutr Cancer 39, 148-153.

13. Motohashi N, Shirataki Y, Kawase M, et al. (2002) Cancer prevention and therapy with kiwifruit in Chinese folklore medicine: a study of kiwifruit extracts. J Ethnopharmacol 81, 357-364.

14. Motohashi N, Shirataki Y, Kawase M, et al. (2001) Biological activity of kiwifruit peel extracts. Phytotherapy Research 15, $337-343$.

15. Collins AR, Harrington V, Drew J, et al. (2003) Nutritional modulation of DNA repair in a human intervention study. Carcinogenesis 24, 511-515.

16. Song P (1984) Healthy application by kiwifruit juice. Nutr Res 6, 35-40.

17. Song P (1984) Anticancer activity of Chinese kiwifruit. Nutr Res 6, 109-114.

18. Imeh U \& Khokhar S (2002) Distribution of conjugated and free phenols in fruits: antioxidant activity and cultivar variations. $J$ Agric Food Chem 50, 6301-6306.

19. Fuke Y \& Matsuoka H (1984) Changes in content of pectic substances, ascorbic acid and polyphenols, and activity of 
pectinesterase in kiwi fruit during growth and ripening after harvest. Japan J Food Sci Technol 31, 31-37.

20. Dawes HM \& Keene JB (1999) Phenolic composition of kiwifruit juice. J Agric Food Chem 47, 2398-2403.

21. Fiorentino A, D'Abrosca B, Pacifico S, et al. (2009) Identification and assessment of antioxidant capacity of phytochemicals from kiwi fruits. J Agric Food Chem 57, 4148-4155.

22. Watjen W, Michels G, Steffan B, et al. (2005) Low concentrations of flavonoids are protective in rat H4IIE cells whereas high concentrations cause DNA damage and apoptosis. $J$ Nutr 135, 525-531.

23. Deschner EE, Ruperto JF, Wong GY, et al. (1993) The effect of dietary quercetin and rutin on AOM-induced acute colonic epithelial abnormalities in mice fed a high-fat diet. Nutr Cancer 20, 199-204.

24. Sánchez-Pérez Y, Carrasco-Legleu C, García-Cuellar C, et al. (2005) Oxidative stress in carcinogenesis. Correlation between lipid peroxidation and induction of preneoplastic lesions in rat hepatocarcinogenesis. Cancer Lett 217, 25-32.

25. Huang RP, Peng A, Golard A, et al. (2001) Hydrogen peroxide promotes transformation of rat liver non-neoplastic epithelial cells through activation of epidermal growth factor receptor. Mol Carcinog 30, 209-217.

26. Cho JH, Cho SD, Hu H, et al. (2002) The roles of ERK1/2 and p38 MAP kinases in the preventive mechanisms of mushroom Phellinus linteus against the inhibition of gap junctional intercellular communication by hydrogen peroxide. Carcinogenesis 23, $1163-1169$.

27. Upham B, Kang K, Cho H, et al. (1997) Hydrogen peroxide inhibits gap junctional intercellular communication in glutathione sufficient but not glutathione deficient cells. Carcinogenesis 18, 37-42.

28. Shi GP, Li Y, Wang QY, et al. (2001) Role of hydrogen peroxide in promoting proliferation and transformation of rat liver oval cell line WB-F344 (article in Chinese). Zhongguo Үі Хие Ке Хие Үиап Хие Вао 23, 346-350.
29. Kang KS, Kang BC, Lee BJ, et al. (2000) Preventive effect of epicatechin and ginsenoside $\mathrm{Rb}_{2}$ on the inhibition of gap junctional intercellular communication by TPA and $\mathrm{H}_{2} \mathrm{O}_{2}$. Cancer Lett 152, 97-106.

30. Brand-Williams W, Cuvelier ME \& Berset C (1995) Use of a free radical method to evaluate antioxidant activity. $L W T-$ Food $S c i$ Technol 28, 25-30.

31. Lee KW, Kim YJ, Lee HJ, et al. (2003) Cocoa has more phenolic phytochemicals and a higher antioxidant capacity than teas and red wine. J Agric Food Chem 51, 7292-7295.

32. Surh YJ (2003) Cancer chemoprevention with dietary phytochemicals. Nat Rev Cancer 3, 768-780.

33. Na HK, Wilson MR, Kang KS, et al. (2000) Restoration of gap junctional intercellular communication by caffeic acid phenethyl ester (CAPE) in a ras-transformed rat liver epithelial cell line. Cancer Lett 157, 31-38.

34. Bruzzone R, White TW \& Paul DL (1996) Connections with connexins: the molecular basis of direct intercellular signaling. Eur J Biochem 238, 1-27.

35. Ruch RJ, Trosko JE \& Madhukar BV (2001) Inhibition of connexin43 gap junctional intercellular communication by TPA requires ERK activation. J Cellular Biochem 83, 163-169.

36. Lee KM, Kwon JY, Lee KW, et al. (2009) Ascorbic acid 6-palmitate suppresses gap-junctional intercellular communication through phosphorylation of connexin 43 via activation of the MEK-ERK pathway. Mutat Res 660, 51-56.

37. Hwang J-W, Park J-S, Jo E-H, et al. (2005) Chinese cabbage extracts and sulforaphane can protect $\mathrm{H}_{2} \mathrm{O}_{2}$-induced inhibition of gap junctional intercellular communication through the inactivation of ERK1/2 and p38 MAP kinases. J Agric Food Chem 53, 8205-8210.

38. Wang H, Cao G \& Prior RL (1996) Total antioxidant capacity of fruits. J Agric Food Chem 701-705.

39. Ko SH, Choi SW, Ye SK, et al. (2005) Comparison of the antioxidant activities of nine different fruits in human plasma. J Med Food 8, 41-46. 